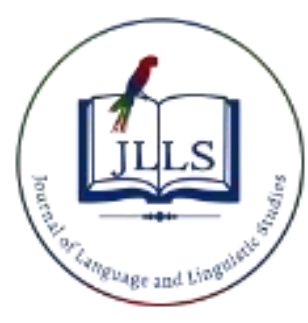

Available online at www.jlls.org

JOURNAL OF LANGUAGE

AND LINGUISTIC STUDIES

ISSN: $1305-578 \mathrm{X}$

Journal of Language and Linguistic Studies, 16(1), 73-88; 2020

\title{
The views of teachers and students on slang in teaching Turkish as a foreign language
}

\author{
Emrah Boylu a 1 (D), Demet Kardaş b ${ }^{\text {iD }}$ \\ a İstnbul Aydın University, İstanbul 34295, Turkey \\ ${ }^{b}$ Gazi University, Ankara 06560, Turkey
}

\section{APA Citation:}

Boylu, E., \& Kardaş, D. (2020). The views of teachers and students on slang in teaching Turkish as a foreign language. Journal of Language and Linguistic Studies, 16(1), 73-88. Doi: 10.17263/jlls.712655

Submission Date:22/01/2020

Acceptance Date:07/03/2020

\begin{abstract}
The aim of this study is to determine the views of teachers and students about the teaching and learning of slang in teaching Turkish as a foreign language. The student-based working group of the study, using a screening model of quantitative research methods, is composed of B1, B2 and C1 level students who learn Turkish as a foreign language reached by means of easily accessible status sampling method of purposeful sampling methods and the teacher-based working group of the study, using a screening model of quantitative research methods, is composed of teachers reached by the same method. The data of the study were collected by two separate questionnaires prepared by the researchers to determine the opinions of teachers and students. Based on the findings of the study, it was concluded that the majority of teachers and students generally had a positive opinion about the learning and teaching of slang words in Turkish and it was concluded that the students wanted to learn slang words because of "better communication with the Turks", "hearing too many slang words on the street", "living in Turkey", "being curious" and "just learning more words". In addition to this result, teachers stated that this situation which students use without knowing the meaning of some words may cause problems in their social environment. For this reason, it is concluded from the teachers' opinions that either a separate book for the use of slang should be published or the other slang words except for swearword should be taught in the lessons.
\end{abstract}

(C) 2020 JLLS and the Authors - Published by JLLS.

Keywords: Teaching Turkish as a foreign language; slang; teacher and student views.

\section{Introduction}

Language is the most fundamental need of a human being, which is formed by changing and developing in a society in thousands of years. People naturally acquire all the riches of their mother tongue. Learning a language other than the mother tongue may still be in the natural flow of life, but in the teaching of Turkish as a foreign language which has become an important field in recent years, it is

\footnotetext{
${ }^{1}$ Corresponding author. Tel.: +0-444-1428-12804

E-mail address: emrahboylu@aydin.edu.tr
} 
quite difficult to determine the limits of the language in the teaching dimension. Although the Common European Framework of Reference for Languages brings a communicative standard to this boundary, it has not been clarified whether or not Turkish slang, which is considered as a forbidden field in speaking or writing, should be taught to a foreign student. In this context, in teaching foreign language teaching in general and in teaching Turkish as a foreign language in particular it is expected that the target language learners will be able to communicate comfortably with the society in which they learn the language. However, considering the changes in the use of language according to the societies' communication needs, living styles and so on, it is known that there are differences between the official language spoken by the target language learners in the classroom and the conversations they hear outside, and that they are frequently expressed by students who do not understand some expressions even though they know the target language at an advanced level. In this context, "slang", which is a part of language and culture and changes and develops according to the communication needs of societies, is generally considered as a shame or swearword and is considered separately from the language and is especially ignored in the field of foreign language teaching. However, in the Common European Framework for Languages (2013: 74), under the heading of perceptual activities and strategies, for the level of $\mathrm{C} 1$ in the set of steps related to understanding television broadcasts and films, the competence "He / she can understand cinema films even if they include sloppy daily language or slang and many idioms." is given. Similarly, when "the Turkish Language Teaching Program as a Foreign Language" prepared by the Maarif Foundation is examined in terms of content, it is seen that "He/she determines the meaning of slang expressions" is included in the $\mathrm{C} 1$ level listening and monitoring acquisitions. (https://www.turkiyemaarif.org) This makes it clear that slang should not be ignored in foreign language teaching.

\subsection{Literature review}

The first connotation that comes to mind when slang is mentioned is that the "profanity" is one of the main reasons for the distance between slang in foreign language teaching. In this context, Aydin summarizes the situation as follows: "This attitude developed by teachers against slang is also related to the evaluation of profanity within the scope of slang. Although there is not much explanation in the sources about the "profanity", which means such as "cursing and bad words", it is often pointed out to the difference with "slang", but no clue is given about how this distinction can be made. However, in general, it can be thought that profanity is separated from the slang with its dominant feature containing insults, slang may be considered to have more specific uses than swearword." (Aydın, 2006:91). "Slang lexemes are commonly described as ephemeral and characteristic of specific social subgroups, whereas swearwords are taboo lexemes that are widely known in the speech communities wherein they occur, do not change quickly from year to year, and are considered taboo by virtue of their semantic link to emotionally charged entities such as human waste and sexuality." (Moore, 2012: 171). In this context, Karaağaç evaluates the profanity, which he defines as "cursing and malediction", under the title of slang. "Cursing and malediction are very complex and may arise from very complex sources. It is an unusual use of language to dissipate the energy that occurs in the nervous system suddenly after an unexpected event." (Karaağaç, 2013: 156). Although it is evaluated under the same title, profanity is another phenomenon. Profanity, as in slang, did not appear to conceal a fact or situation, but to insult by revealing the hidden and shameful phenomenon. They do not belong to a group as in slang and are used by all segments of the society or are known even if they are not used." (Akar, 2014: 31). Even though the profanity is discussed under the title of slang based on this information, it should be known that swearwords should not come to mind directly. In this context, the slang is defined by Devellioğlu (1990: 14) as "a special language which is formed in every country in every language by different segments or groups in order to provide agreement in a different way." Çifçi, (2006: 297) expresses his opinion about 
slang as follows: In any way and for whatever purpose, it can be said that all means of expression meet the specific needs of people, individually and as a society, and are therefore functional. Of course, so is slang; its emergence is based on certain needs." Easy communication, the effort to form a common language, the use of analogies, make the slang part of language and literature. The use of slang in verbal language makes the slang a part of spoken language. "Slang is a kind of conversation. The linguistic characteristics of a type of speech can be found at the verbal, phonological, morphological or syntactic level of the language" (Izmaylova et al. 2017: 75).

Foreign language teaching involves active interaction with the target language culture, without which a person is not able to fully master the language and achieve mutual understanding with the native speaker (Korolyova, Voyakina and Melekhova, 2016: 94). In this context, slang is one of the most fundamental facts that restrict the interaction of native language users and those who learn that language as a foreign language. Because it is a difficult action for foreign language students to know the slang words literally that belong to a language and to use them appropriately. This brings a limited use of language for foreign language learners. Whereas Fein (2011: 97-101) states that foreign language students clearly demonstrated the necessity of slang teaching on subjects such as being able to communicate with native speakers and their peers, making new friends, not wanting to look different, traveling comfortably to a country where they learn their language, and asking their peers to be influenced by their local dominance. Because Elsherif and Nsir (2015: 6) also emphasize that slang teaching can motivate students to learn the language and will improve students' informal communication skills as well as the use of the relevant authentic language.

Based on the above information, written and visual publications, computer games, series, films can be said to make the slang part of social life and language. Therefore, ignoring the slang of a language when learning or teaching a language will leave a learner incomplete on the street, on the bus, in the dorm, in all areas of social life. However, those who learn Turkish as a foreign language often hear slang from their Turkish peers and on the street in their social environments. Therefore, the student's confidence may be diminished by encountering an unknown or incomprehensible slang. For example, a student who does not know the meaning of words such as the word "kazık": very difficult for students, a very difficult exam for students (Aktunç, 1998: 171), the word "ineklemek": studying intensively, memorizing the course (Aktunç, 1998: 149), the word "asmak": not going to school, class (Aktunç, 1998: 45) may have difficulty in communicating with friends with the feeling that he does not know Turkish in full sense. For this reason, Aydin (2016) states that it is necessary to mention slang in order to present Turkish vocabulary in all its richness in teaching Turkish as a foreign language. For this reason, many studies have been conducted on slang, especially in teaching English as a foreign language (Charkova, 2007; Mazer and Hunt, 2008; Fein, 2011; Dinçay, 2012; Senefonte, 2014; Korolyova, Voyakina, and Melekhova, 2016; Kang, 2019), but in teaching Turkish as a foreign language, not much work (Aydin, 2016a; 2016b) has been done. In this context, this study is important in terms of providing students' and teachers' opinions about slang teaching from the related field. In this context, the purpose of the study is to determine the views of Turkish language learners and teachers as a foreign language for the learning and teaching of slang words.

\subsection{Research questions}

The questions sought in the research are as follows:

1- What are the views of the students regarding their desire to learn Turkish slang words?

2- What are the teachers' views on the teaching of slang words in Turkish?

3- What are the views of teachers about the state of contributing to students knowing Turkish slang in terms of communication dimension of language? 
4- What is the state of the students asking slang words in Turkish to teachers?

5- What is the status of teachers to teach slang words in lessons?

\section{Method}

In this study, which aims to determine the views of Turkish language teachers and learners about the teaching and learning of slang, a screening model of quantitative research methods is used. The screening model depicts a past or present situation and attempts to identify the individual or object as it is within its own circumstances. In this model, the expression of the objectives consists of question sentences such as "what was it?", "what is that", "what is it about?", and "what does it consist of?" (Karasar, 2012: 77).

\subsection{Sample / Participants}

The student-based working group of the study consists of B1, B2 and C1 level students who learn Turkish as a foreign language reached by means of easily accessible status sampling method of purposeful sampling methods. In the research, it was determined that the students who will be included in the study group should be at least B1 level based on their ability to give opinions about slang and understand the questions in the questionnaire. Demographic information of the relevant working group is as follows:

Table 1. Information on Students' Levels and Gender

\begin{tabular}{lccc}
\hline Level & Male & Female & Overall Total \\
\hline B1 & 15 & 12 & 27 \\
\hline B2 & 26 & 52 & 78 \\
\hline C1 & 22 & 24 & 46 \\
\hline Overall Total & 63 & 88 & 151 \\
\hline
\end{tabular}

When the table is examined, it is seen that 27 of 151 students are B1, 78 of them are B2 and 46 of them are in $\mathrm{C} 1$ level. 63 of these students are male and 88 of them are female.

Table 2. Information on Students' Countries

\begin{tabular}{lllllc}
\hline Country & Number & $\boldsymbol{\%}$ & Country & Number & $\%$ \\
\hline USA & 1 & 0.66 & Cameroon & 1 & 0.66 \\
\hline Afghanistan & 8 & 5.29 & Egypt & 3 & 1.98 \\
\hline Arabia & 1 & 0.66 & Serbia & 2 & 1.32 \\
\hline Algeria & 1 & 0.66 & Somalia & 1 & 1.32 \\
\hline China & 1 & 0.66 & Syria & 61 & 40.39 \\
\hline Morocco & 1 & 0.66 & Tajikistan & 1 & 0.66 \\
\hline Palestine & 7 & 4.63 & Tunisia & 2 & 1.32 \\
\hline Croatia & 34 & 22.51 & Ukraine & 1 & 0.66 \\
\hline Iraq & 12 & 7.94 & Jordan & 2 & 1.32 \\
\hline Iran & 10 & 6.62 & & & 151 \\
\hline Spain & 1 & 0.66 & Total & 100 \\
\hline
\end{tabular}


Table 2 shows that a total of 151 students from 20 different countries participated in the study. When we look at the information from which countries the students are from, 61 of them are from Syria, 34 are from Croatia, 12 are from Iraq, 10 are from Iran, 8 are from Afghanistan, 7 are from Palestine, 3 are from Egypt, and 1 or 2 students are from other countries.

The teacher-based working group of the study consists of 104 teachers reached by means of easily accessible status sampling method of purposeful sampling methods as well. The personal information of the relevant teachers is as follows:

Table 3. Information on teachers' gender and place of work

\begin{tabular}{lccc}
\hline & Abroad & Domestic & Overall Total \\
\hline Male & 4 & 33 & 37 \\
\hline Female & 3 & 64 & 67 \\
\hline Overall Total & 7 & 97 & 104 \\
\hline
\end{tabular}

When the table is examined, it is seen that 37 of the teachers are male and 67 of them are female. In addition, it is understood that 7 of the teachers teach Turkish as a foreign language abroad and 97 of the teachers teach Turkish as a foreign language in Turkey. Information on the experiences of the relevant teachers is given in Table 4 below:

\subsection{Instrument(s)}

The data of the study were collected through 2 questionnaires prepared by the researchers to collect views of teaching and learning slang words of Turkish teachers and learners as a foreign language. One of the related questionnaires was prepared to determine the opinions of teachers and the other for the students' views. While preparing the related questionnaires, opinions were obtained from 3 experts and the questionnaires were finalized.

\subsection{Data collection procedures}

To collect the data of the research, firstly, a literature review was conducted. The purpose of conducting the relevant screening is to determine whether there are currently any questionnaires or scales on the determination of the opinions of both teachers and students about slang. However, any tool could not be reached and questionnaires for both groups were started to be prepared by the researchers. In this context, it was adhered to the stages of preparing questionnaires and the opinions of the questionnaires were finalized by applying expert opinions for the prepared questionnaires. From the finalized questionnaires, two students who learned Turkish at B1 level were asked to read the questionnaire, and the parts that were not understood were made linguistically understandable. The questionnaires, which are ready for implementation, were applied to those who teach and learn Turkish as a foreign language based on volunteerism in the 2018-2019 spring semester. The implementation of the questionnaires was completed within a month and the analysis of the data started.

\subsection{Data analysis}

While the researchers were analyzing the data they obtained with two different questionnaires, they analyzed closed and open-ended questions separately. In this context, firstly the data obtained were transferred to the excel file and the answers given to the questions in the questionnaires were transferred to the tables by making content analysis. While analyzing the answers given to open-ended questions by teachers and students, reorganization and combining of some expressions was made. After these 
processes, the data in the tables are presented with percentages and frequencies, making the reader more comfortable to understand.

\section{Results}

\subsection{What are the views of the students regarding their desire to learn Turkish slang words?}

Table 4. Findings of students' desire to learn slang words in Turkish

\begin{tabular}{lll}
\hline Opinion & Number & \% \\
\hline I want. & 111 & 73.51 \\
\hline I don't want. & 40 & 26.49 \\
\hline Overall Total & 151 & 100 \\
\hline
\end{tabular}

Table 4 shows that $73.51 \%$ of the 151 students want to learn slang words in Turkish and $26.49 \%$ of them don't want to learn slang words in Turkish. In this context, it can be said that the students' opinions about learning slang words are positive. Findings about how students' desire status for learning slang words are distributed according to their gender are as follows:

Table 5. Findings of students' desire to learn slang words by gender

\begin{tabular}{lll}
\hline & Number & \% \\
\hline I want. & 111 & 73.50 \\
\hline Male & 48 & 76.19 \\
\hline Female & 63 & 71.59 \\
\hline I don't want. & 40 & 26.49 \\
\hline Male & 15 & 23.81 \\
\hline Oemale & 25 & 28.41 \\
\hline
\end{tabular}

In Table 5, it was found that 48 of the 111 students, who want to learn slang words, are male; 63 of them are female; and 40 of those who do not want to learn are 15 male and 25 of them are female. Based on the gender distribution of 151 students participating in the study, Table 1,76.19\% of 63 male students and $71.59 \%$ of 88 female students wanted to learn slang words. The reasons for those who want to learn slang words are as follows:

Table 6. Reasons for those who want to learn slang words

\begin{tabular}{lcc}
\hline Reason & Number & \% \\
\hline Better communication with Turks & 28 & 29.16 \\
\hline Hearing too many slang words on the street & 24 & 25.00 \\
\hline Living in Turkey & 27 & 28.12 \\
\hline Being curious & 11 & 11.45 \\
\hline Just learning more words & 6 & 6.25 \\
\hline Total & 96 & 100 \\
\hline
\end{tabular}


When Table 6 is examined, it is seen that 96 of the 111 students who want to learn slang words in Turkish are categorized. In this context, $29.16 \%$ of the students explained why they wanted to learn slang words because of "better communication with Turks"; $25 \%$ of them want because of "hearing too many slang words on the street"; $28.12 \%$ of them want because of "living in Turkey"; $11.45 \%$ of them want because of "being curious"; and $6.25 \%$ of them want because of "Just learning more words". Within this framework, the opinions of the students are as follows:

Table 7. Students' views on learning slang words

S116: To communicate with the Turks.

S108: Slang doesn't always mean profanity. I want to learn daily Turkish language to get along with the Turks better.

S117: Because it is used today and we need to know.

S43: I'll live in Turkey, I'll meet with the Turks. Therefore I want to learn slang to deal with people.

S34: Because sometimes when a stranger tells us something bad, we can't say anything, and sometimes slang words are important to jerk people.

S22: Because we need it, sometimes we have to use it.

59: Because I want to understand street language.

S18: Because I have to use it on the street and we are already living in Turkey then we have to learn everything about Turkish.

S89: Because all Turks use slang words, so we have to learn slang words to understand them better.

S1: Because I have Turkish friends and I can chat with them with more interesting slang words.

S91: Because Turkish people use slang words frequently in their daily lives and we need to learn these words so that we can understand their meaning when told to us.

S45: Because Turks generally speak using slang words.

S2: Because it is an important part of the conversations of daily life.

S33: I live in Turkey because it is what I need, I need to know the language exactly.

S151: Learning words is a very important and valuable thing.

S15: I wonder.

S100: There is no reason but I want to learn because I do not know some slang words while the Turks are talking.

S29: I want to answer severely to the jerk man.

S44: It can help me use on the streets.

S42: If people on the street use swearwords, we need to know the words of profanity and slang in order to understand it.

S53: I want to use it with my Turkish friends and I want to understand them when they use slang words.

S49: We need to know if there's anything happening.

S114: Sometimes I didn't understand what someone was saying when they were swearing at me.

S79: Because sometimes Turks blame the Syrians and I don't understand much because I don't know.

S60: Because people speak some slang in the street.

S75: I would, but not to use it, to understand.

S58: They use it on buses.

S56: Just to know, not to use it. I can understand when someone says it in front of me.

S82: To understand the words I hear on the street.

S4: I can speak like a Turk.

S65: Turks speak slang words with me. 
S122: Don't let them know that I am a foreigner because when I talk like that, they will not realize that I am a foreigner. They'll think I'm Turkish.

When we look at the above opinions, the students stated that they often hear slang words in daily life, that they wanted to understand what was said, if not to use it, that they had an important place in daily life conversations and they were curious.

\subsection{What are the teachers' views on the teaching of slang words in Turkish?}

Table 8. Findings related to teachers' opinions about teaching slang words in Turkish

\begin{tabular}{lll}
\hline Opinion & Number & \% \\
\hline Yes. I consider it necessary. but I do not teach. & 22 & 21.15 \\
\hline Yes. I consider it necessary and I teach. & 38 & 36.53 \\
\hline No. I don't think it's necessary. & 44 & 42.30 \\
\hline Overall Total & 104 & 100 \\
\hline
\end{tabular}

Table 8 shows that $21.15 \%$ of the 104 teachers who participated in the study deemed it necessary for students to learn slang words, but it was found that they favored not to teach, $36.53 \%$ deemed it necessary and taught at the same time and $42.30 \%$ did not deem it necessary. In this context, $57.68 \%$ of 104 teachers reported that students should learn slang words. In this context, when the tables 6 and 9 are interpreted together, it can be said that the majority of students $(73.51 \%)$ and teachers $(57.68 \%)$ who participated in the research had a positive opinion about the learning and teaching of slang words in Turkish.

Table 9. Findings related to the learning of slang words in Turkish by the teachers' gender

\begin{tabular}{lcc}
\hline Gender and Opinion & Number & $\%$ \\
\hline Male & 37 & 27.02 \\
\hline Yes. I consider it necessary. but I do not teach. & 10 & 27.02 \\
\hline Yes. I consider it necessary and I teach. & 10 & 45.94 \\
\hline No. I don't think it's necessary. & 17 & 17.91 \\
\hline Female & 67 & 41.79 \\
\hline Yes. I consider it necessary. but I do not teach. & 12 & 40.29 \\
\hline Yes. I consider it necessary and I teach. & 28 & 100 \\
\hline No. I don't think it's necessary. & 27 & 104 \\
\hline Overall Total
\end{tabular}

Looking at Table 9, 20 of the 37 male teachers who participated in the study deemed it necessary for students to learn slang words and 17 of them did not. However, 40 out of 67 female teachers who participated in the research thought that students need to learn slang words and 27 of them considered it unnecessary. In this context, it can be concluded that female teachers want students to learn slang words more than male teachers.

3.3 What are the views of teachers about the state of contributing to students knowing Turkish slang in terms of communication dimension of language? 
Table 10. Does knowing Turkish slang gain something to students in terms of communicative dimension of language?

\begin{tabular}{lcc}
\hline Opinion & Number & \% \\
\hline Yes & 30 & 28.84 \\
\hline No & 26 & 25.00 \\
\hline Partly & 48 & 46.15 \\
\hline Overall Total & 104 & 100 \\
\hline
\end{tabular}

Looking at Table 10, 28.84\% of the teachers participating in the research stated that knowing Turkish slang would gain something to the student in terms of the communicative dimension of the language, while $25 \%$ stated that it would not and $46.15 \%$ said that it would partially gain. In this context, the reasons of the teachers who stated that knowing Turkish slang will contribute to the student in terms of communicative dimension of language are as follows:

Table 11. Opinions of teachers who stated that knowing slang in Turkish would contribute to the student in terms of communicative dimension of language

T1: Slang is also an element of language. It should be taught.

T90: Slang is a part of the language used and lived. Slang uses should be given in contexts that will be created authentic.

T8: Slang is one of the communicative dimensions of language. I did not abstain from teaching slang words while teaching Turkish in Iran. Because the learner heard this in the movies. If he does, it's in the language. There's no point in ignoring it. People living in Turkey already hear them. When they don't know what it means, they can react wrongly. It is useful to include slang teaching in the process of teaching Turkish as a foreign language abstemiously.

T29: I think it is necessary for the professional use of slang. Slangs can be given that will not cause problems in the student's life. Slangs that cause problems can also be explained appropriately and it can be stated that the use of them will be a problem.

T16: Slang words are absolutely necessary but except for badly meaningful ones.

T79: Learning slang words can make us know what we shouldn't use in our daily life, but the further away we are, the better.

T95: Slang is not only abusive speech but an upper language, so teaching it will be more efficient in terms of communication.

T74: Slang and profanity must be included in language teaching. Slang and profanity also reveal the culture of a society. Culture is also transferred through profanity and slang. Negative situations in slang reflect the values and perspectives of society.

T4: Slang is the living and developing side of the street as well as the academic part of language. Even if it does not suit the textbooks and texts, the instructor should also have a good command of the street language and if necessary the instructor should be able to teach them in order to have a command of the living language.

T25: As the student learns and uses slang words, he / she feels closer to the target language. As a matter of fact, he / she shares his / her new slang words with his / her friends and enables them to learn and use them. Although it is an approach by some teachers that slang words should not be taught and the student should not use slang words, there is a fact that slang words are in the living language, and the student can access these words anytime, anywhere. Even if not taught for this reason, I think the answer should be given when the student asks.

T104: Some students try to speak as they hear from the street, and because they do not know the language exactly, they naturally think it is true. In the classroom environment they use appeals such as "my lad!" He won't actually use it if he finds out what it means, it's not polite. For this reason, I explain and teach that there is something wrong and I think it is necessary to teach it.

T75: I think that although it is an abstract concept that can be explained in a clear and understandable way for the c level, it can be made more fun to think that the inner features and closed style of Turkish make it more understandable. Video can be supported with listening texts. 
T102: I think it is absolutely necessary for a student who wants to live in Turkey.

T48: Although we are distant to this subject in general, but if we teach living Turkish, I think that they should be given. If the student does not meet them in the course, he will surely encounter them on the street or hear them on television.

T18: The child can decide whether to use the slang words in our language by communicating with Turkish friends in the park, in the market and observing the results of the slang words indirectly. The aim is to know the meaning of slang words but not to use them. The child will not use the slang words with this communication barrier realizing that they are wrong.

T85: Since language learning is learned by living, I think that students should learn all the elements we use in everyday language. Of course, we need to put a limit on this issue, not to confuse slang and profanity. T97: I am in favor of teaching language from the environment while teaching language. For this reason, the words we call slang are actually bad in terms of meaning, but they are very effective in making strong analogies. The teacher should take this responsibility in teaching this. Because if the student wants to learn these words from the social environment outside the teacher, he / she is often the victim of his / her ignorance. For example, the meaning of the word is very bad, but his / her friends teach him / her it as a good thing. This causes the student to experience difficulties in social life.

T7: It should be taught except swearwords. A separate book should be published.

T100: Students know these words as bad and use them, but they don't know exactly what they means. They need to be fully explained and taught how rude words are.

T31: I think the student should know these things but I don't find it right to be taught in a formal education. Extra-curricular learning should be encouraged to learn because they are a part of life, whether we like it or not.

T55: Students need to be taught to know that the other person is swearing them.

T56: I think it should be taught and the words should systematically remove.

T94: Turkish slang is very colorful and rich. Teaching slang words will make it easier for students to understand this structure. In this sense, slang should not be seen as a taboo and should be taught to students.

T82: International students who learn Turkish as a foreign language often hear slang words. Especially slang words written in articles are the words used by young people in almost every sentence. These words should never be taught to foreign students in the classroom. I think that this is incompatible with professional ethics and will undermine respect for the teacher, but I think it should be explained correctly when students ask the meaning of the words. I think it is inevitable to learn these slang words spontaneously.

T11: Students who know slang words will have the opportunity to look at the subtleties and riches of Turkish from a different point of view.

When the above views are considered, teachers state that students often hear slang words and learn these words from social circles in some way. Therefore, the teachers expressed their opinions about the necessity of either creating a separate book or teaching slang words other than profanity taking into consideration that this situation which students use without knowing the meaning of some words may put them in trouble in the social environment they live in.

\subsection{Findings about students' probability to ask slang words in Turkish to teachers}

Table 12. Students' probability to ask slang words in Turkish to teachers

\begin{tabular}{lll}
\hline Opinion & Number & $\%$ \\
\hline Yes & 37 & 24.50 \\
\hline No & 65 & 43.04 \\
\hline Partly & 49 & 32.45 \\
\hline Total & 151 & 100 \\
\hline
\end{tabular}

When Table 12 is examined, it is seen that while $24.50 \%$ of the students can ask slang words to their teachers in Turkish, $43.04 \%$ could not, and $32.45 \%$ could partially ask them. When we look at the 
information about the distribution of students' probability to ask slang words in Turkish to teachers according to gender, the situation is as follows:

Table 13. Students' probability to ask slang words to teachers according to their gender

\begin{tabular}{llc}
\hline Gender & Number & $\%$ \\
\hline Male & 16 & 25.39 \\
\hline Yes & 29 & 46.03 \\
\hline No & 18 & 28.57 \\
\hline Partly & 63 & 100 \\
\hline Total & & 23.86 \\
\hline Female & 21 & 40.90 \\
\hline Yes & 36 & 35.22 \\
\hline No & 31 & 100 \\
\hline Partly & 88 & 100 \\
\hline Total & 151 & \\
\hline Overall Total & & \\
\hline
\end{tabular}

Looking at Table 13, 16 of 37 students who can ask slang words in Turkish are male, 21 are female; it was found out that 29 of the 65 students who could not ask were male and 36 of them were female. When the gender status and the probability to ask slang words in Turkish to teachers are evaluated within themselves, it is seen that $25.39 \%$ of 63 male students and $23.86 \%$ of 88 female students could ask slang words to their teachers. It is a striking finding that the proportions of both groups are close to each other. However, it is noteworthy that the ratio of male students (46.03\%) is higher than female students $(40.90 \%)$ in both groups (male-female) who cannot ask slang words to their teachers.

Table 14. Status of students asking them slang words according to teachers

\begin{tabular}{lll}
\hline Opinion & Number & $\boldsymbol{\%}$ \\
\hline Yes & 49 & 47.11 \\
\hline No & 23 & 22.11 \\
\hline Partly & 32 & 30.76 \\
\hline Overall Total & 104 & 100.00 \\
\hline
\end{tabular}

Looking at Table 14, $47.11 \%$ of the 104 teachers participating in the research stated that students could ask themselves slang words, $22.11 \%$ could not ask, and $30.76 \%$ said they could ask partially.

\subsection{Findings about teachers' use of slang words in lessons}

Table 15. Teachers' use of slang words in lessons according to students

\begin{tabular}{llc}
\hline Opinion & Number & \% \\
\hline The teacher uses slang words in lessons. & 37 & 24.50 \\
\hline The teacher doesn't use slang words in lessons. & 114 & 75.49 \\
\hline Overall Total & 151 & 100 \\
\hline
\end{tabular}

When Table 15 is examined, it is seen that $24.50 \%$ of the total 151 students who participated in the research stated that teachers used slang words in the lessons and $75.49 \%$ stated that they did not. In this 
context, the findings of 114 students who stated that the teachers did not use slang words in the lessons were as follows:

Table 16. Students who want to learn slang words by stating that teachers do not use slang words

\begin{tabular}{llc}
\hline Opinion & Number & $\%$ \\
\hline Yes. I want. & 84 & 73.68 \\
\hline No. I do not want. & 30 & 26.31 \\
\hline Overall Total & 114 & 100 \\
\hline
\end{tabular}

When the table is examined, it is concluded that $73.68 \%$ of the 114 students who stated that the teachers did not use slang words in the lessons wanted the slang words to be told and that $26.31 \%$ did not want to be told.

\section{Discussion}

In the study, it was concluded that the majority of students and teachers had positive opinions about the learning and teaching of slang words in Turkish. The results are similar to those of Aydin (2016) and Fein (2011). In both studies, as in this study, students want to include slang in language teaching. In this context, Dinçay (2012: 25) states that slang is becoming more widespread nowadays; even in verbal and written media, the use of slang makes itself felt; therefore, a person who learns a foreign language in Turkish schools has difficulty in communicating with young people, especially when traveling abroad; slang language should be integrated into curricula in schools; in this way, students will have more confidence in themselves; and they can better understand TV series broadcasted in foreign languages and communicate easily with their young peers. Aydin (2016: 322) likewise states that it is essential for the learners of Turkish as a foreign language to have information about Turkish slang in order to communicate more easily in daily language. Therefore, the argument should not be seen as a taboo and the Turkish slang should be taught to the students.

Similar to the outcome of this study, Ertan Dalak (2017: 17) states that slang has difficulties in teaching foreign languages, which provides significant indicators about the sociological and cultural status of a language, therefore he states that a separate dictionary should be used to understand slang words and phrases. In addition to this information, some teachers have emphasized the importance of providing information about such words to prevent students from using slang words unconsciously. Likewise, Murray (2011: 85) states that without teachers' guidance, EFL students cannot distinguish ways to constructively use their excitement about English slang to improve their general English skills, therefore Murray states that teacher guidance is important for increasing students' English proficiency, personalizing their learning, and directly participating in the learning process (by Kang, 2019: 91). In this context, it is understood that it is an important issue for teachers to act as guides for students during the learning of slang words. Because Kang (20019: 91) in his work with teachers and students titled " "Wicked' use of English slang in relation to identity development in an elementary EFL classroom" focused on the effectiveness of English slang use and learning in relation to the identity building of the EFL student, and suggested that elementary EFL students would provide more comprehensive diagnoses about their use and learning of English slang and how their identity was restructured through use and learning. This also reveals the importance of slang in foreign language teaching.

In the research, some of the teachers stated that slang teaching would not be appropriate in the classroom. Similarly, in his study, Senefonte (2014: 71) stated that slang teaching is very limited in English classes in Brazil due to its semantic features. In this context, Fein (2011: 98), who argued that 
slang teaching is absolutely necessary, explains why teachers do not favor slang teaching as follows: "We, as language teachers, as those who set the basic standards for acceptable language use, may simply have a hidden bias against teaching slang. Or we may believe that slang belongs to an area of cultural experience that lies outside the limits of the classroom. We may assume, and there is a certain logic to this assumption, that slang is best taught by those who use it the most in the places where it is used most frequently - that is, by student peers in the street, in bars, at parties, etc. Why waste valuable class time on vocabulary of dubious value that students will inevitably pick up on their own? "Whereas Korolyova, Voyakina and Melekhova (2016: 101) argue that teachers should be taught the slang, which is part of the culture, in addition to developing students' four basic language skills, especially using some special teaching techniques. Based on all these information and findings, it can be said that slang teaching and learning are important in teaching Turkish as a foreign language, therefore it should be studied more in the academic context and should be handled with various aspects.

\section{Conclusions}

It was concluded that the students who participated in the research wanted to learn slang words because of "better communication with the Turks", "hearing too many slang words on the street", "living in Turkey", "being curious" and "just learning more words". It was also found out that the students agreed that learning slang words in Turkish is "important".

In the study, $28.84 \%$ of the teachers stated that knowing slang in Turkish would gain something to the student in terms of communicative dimension of the language, while $25 \%$ said that it would not and $46.15 \%$ said that it would partially gain. Teachers state that students often hear slang words and learn these words from social circles in some way. For this reason, teachers stated that slang words should be taught by taking into consideration that this situation which students use without knowing the meaning of some words may cause problems in their social environment. Looking at the situation of being able to ask slang words to teachers in Turkish, $24.50 \%$ of the students stated that slang words in Turkish could be asked to their teachers while $43.04 \%$ stated that slang words in Turkish could not be asked to their teachers. In terms of gender, it is concluded that there is no significant difference between male and female students' probability to ask slang words to teachers.

In terms of teachers, looking at the students' state of asking slang words to teachers, $47.11 \%$ of the teachers who participated in the research stated that the students could ask them slang words and it was concluded that $63.26 \%$ of these teachers were female and $36.73 \%$ were male.

In terms of teachers' use of slang expressions in the lessons, $24.50 \%$ of the students who participated in the research stated that the teachers used slang words in the lessons and $75.49 \%$ did not. In this context, it is concluded that $73.68 \%$ of 114 students who stated that teachers did not use slang words in the lessons wanted slang words to be told and $26.31 \%$ did not want to tell slang words.

Based on these results, the following suggestions can be listed:

- In order to enable Turkish language learners to use the language fully functional and not to have any difficulties in communication, the teaching of slang should be included in the lessons.

- It should be known that swearwords should not come to mind first when slang is said and that should be taught to the students.

- A list of slang words that can be taught according to levels should be prepared.

- Dictionaries in which students can learn Turkish slang words should be prepared.

- Frequency studies of slang words should be included in the frequency studies conducted in the field of teaching Turkish as a foreign language.

- The number of academic studies in the field on the necessity of teaching slang should be increased. 


\section{Ethics Committee Approval}

The authors confirm that this study does not need ethics committee approval. (Date of Confirmation: 21.03.2020)

\section{References}

Akar, A. (2014). Türk sözlük biliminde tanımsız bir alan: Sövgü sözleri. Dil Araştırmaları, 14, 27-33.

Aktunç H. (1998). Büyük argo sözlüğ̈̈. İstanbul: Yapı Kredi Yayınları.

Aydın, H. (2006). G.o.r.a. filmindeki argo ve küfür kullanımının mizahi işlevi. Millî Folklor, 18(71), 90-95.

Aydın, Y. (2016). Yabancı dil olarak Türkçe öğrenen öğrencilerin argoya ilişkin görüşleri. Uluslararası Türk Dili ve Edebiyatı Araştırmaları Dergisi, 5(11), 9-18.

Aydın, Y. (2016). Yabancı dil olarak Türkçe öğretiminde argonun yeri üzerine bir tartışma. Amasya Üniversitesi Eğitim Fakültesi Dergisi, 5(2), 308-326.

Charkova, K. D. (2007). A language without borders: English slang and Bulgarian learners of English. Language Learning, 57(3), 369-416.

Çifçi, M. (2006). Argonun niteliği ve argoya bakış açımız. Journal of Turkish World Studies, 6(2), $297-$ 301.

Devellioğlu, F. (1990). Türk argosu. Ankara: Aydın Kitabevi Yayınları.

Dinçay, T. (2012) Why not teach slang in the classroom. Dil Dergisi, 155, 24-34.

Elsherif, E. and Nsir, N. (2015). İntroducing slang to English language learners. Ohio Teachers of English to Speakers of Other Languages. 7(3). 6-9.

Ertan Dalak, D. H. (2017). Yabancı dil olarak Türkçe öğretiminde iletişimsel yaklaşımın deyim ögrretimindeki başarıya etkisi. Yayımlanmamış Yüksek Lisans Tezi. Hacettepe Üniversitesi Türkiyat Araştırmaları Enstitüsü. Ankara.

Fein, D. A. (2015). Promoting vulgarity by teaching slang in the classroom. Rocky Mountain Review, (65), 1 .

Heiman, E. (1967). The use of slang in teaching linguistics. The English Journal, 56(2), 249-252.

Izmaylova, G. A., Zamaletdinova, G. R., Zholshayeva, M. S. (2017). Linguistic and social features of slang. International Journal of Scientific Study, (15), 6, 75-78.

Kang, D. M. (2019). 'Wicked' use of English slang in relation to identity development in an elementary efl classroom. An International and Interuniversity Journal of Foreign Language Didactics, 31, 75 95 .

Karasar, N. (2012). Bilimsel araştırma yöntemi. Ankara: Nobel Yayınları

Korolyova, L. Yu., Voyakina, E. Yu. and Melekhova, N. V. (2016). Slang and metaphors in the process of teaching english as a foreign language. Journal Problems of Contemporary Science and Practice, 61, 94-103. DOI: 10.17277/voprosy.2016.03. pp.094-103. 
MEB Talim ve Terbiye Kurulu Başkanlığg Çeviri Komisyonu (2013). Diller için Avrupa ortak başvuru metni öğrenme öğretme değerlendirme. Ankara: Talim Terbiye Kurulu Başkanlığı Yayınları.

Moore, R. L. (2012). On swearwords and slang. American Speech, 87(2), 170-189.

Murray, G. (2011). Identity, motivation and autonomy: Stretching our boundaries, in G. Murray, X. Gao, \& T. Lamb (Eds.), Identity, motivation and autonomy in language learning (pp. 247-262). Bristol, England: Multilingual Matters.

Rahmaniah, S. (2018). Teaching politeness of using slang in speaking: Analysis of conversations in tuesdays with morrie. Jurnal Tarbiyah: Jurnal Ilmiah Kependidikan, 7 (1), 25-36.

Senefonte, F. H. R. (2014). Discourses on slang: implications for English classes in Brazil. Working Papers em Linguistica, 15(1), 71-83. http://dx.doi.org/10.5007/1984-8420.2014v15n1p71.

Terzioğlu, Ö. (2006). Anonim bir halk edebiyatı ürünü olarak argo. Millî Folklor, 18(71), 102-106. https://turkiyemaarif.org/post/7-turkcenin-yabanci-dil-olarak-ogretimi-programi-1080?lang=tr.

\section{Yabancı dil olarak Türkçe öğretiminde argo üzerine öğretmen ve öğrenci görüşleri}

\section{$\ddot{O} \mathbf{z}$}

Çalışmanın amacı, yabancı dil olarak Türkçe öğretiminde argonun öğrenimi ve öğretimine yönelik öğretmen ve öğrenci görüşlerini tespit etmektir. Nicel araştırma yöntemlerinden tarama modeli kullanılan araştırmanın öğrenci temelli çalışma grubunu, amaçlı örnekleme yöntemlerinden kolay ulaşılabilir durum örneklemesi yöntemi ile ulaşılan yabancı dil olarak Türkçe öğrenen B1, B2 ve C1 düzeyindeki öğrenciler, öğretmen temelli çalışma grubunu ise aynı yöntem ile ulaşılan öğretmenler oluşturmaktadır. Araştırmanın verileri, araştırmacılar tarafından öğretmen ve öğrencilerin görüşlerinin tespitine yönelik hazırlanan 2 ayrı anket ile toplanmıştır. Araştırmadan elde edilen bulgulardan hareketle öğretmen ve öğrencilerin büyük bir çoğunluğunun Türkçe argo kelimelerin öğrenimi ve öğretimine yönelik genel olarak olumlu görüşe sahip oldukları, öğrencilerin argo kelimeleri "Türklerle daha iyi iletişim kurabilmek", "Sokakta çok fazla argo kelime duyulması", "Türkiye'de yaşanması", "Merak etme" ve "Sadece daha fazla kelime öğrenme" gerekçesi ile öğrenmek istedikleri sonucuna ulaşılımıştır. Bu sonuca ek olarak öğretmenler, öğrencilerin bazı kelimelerin anlamlarını bilmeden kullandıkları bu durumun da onların yaşadıkları sosyal çevrede sıkıntıya sokabileceği belirtmişlerdir. Bu nedenle öğretmenlerin görüşlerinden de hareketle argonun kullanımına yönelik ya ayrı bir kitap çıkarılması ya da küfür hariç diğer argo kelimelerin derslerde öğretilmesi gerekliliği sonucuna ulaşılmıştır.

Anahtar sözcükler: Yabancı dil olarak; Türkçe öğretimi; argo; öğretmen ve öğrenci görüşleri

\section{AUTHOR BIODATA}

Emrah Boylu, completed his master's thesis titled "Levels of Using Language Learning Strategies of Learners of Turkish as a Foreign Language" in 2015, and his PhD thesis titled "Measurement and Evaluation Applications in Teaching Turkish to Foreigners and Creating a Standard" in 2019 at Gazi University. Between 2012 and 2015, he 
worked as an Education Coordinator of Yunus Emre Turkish Culture Center in Iran's capital Tehran and he worked as an Education Coordinator of Istanbul Aydın University TÖMER between 2015 and 2017 and since 2018 he has been working as the director of the same unit. The author has many academic studies in the related field.

Demet Kardaş, completed her master's thesis titled "A Research on Written Expressions of Gendarmerie NCO Vocational School Students" in 2007, and her PhD thesis titled "Factors Affecting the Reading Comprehension Development of Disadvantaged Students and Suggestions for Solutions" in 2014 at Gazi University. Between 2011 and 2016, she worked as a lecturer at Gazi University TÖMER and since 2016 she has been working as a Turkish lecturer in the Department of Turcology, Faculty of Philosophy at the University of Zagreb. She has several academic studies on Turkish education and teaching Turkish to foreigners. 